\title{
Interface of non-communicable diseases and infections in Africa
}

\author{
James K Tumwine
}

Department of Paediatrics and Child Health, School of Medicine, Makerere University, Kampala, Uganda.

DOI: https://dx.doi.org/10.4314/ahs.v18i4.1

cite as: Tumwine JK. Interface of non-communicable diseases and infections in Africa. Afri Health Sci. 2018;18(4): i-iv. https:// dx.doi.org/10.4314/abs.v18i4.1

This time it is non-communicable diseases first, followed by infections! The first seven papers in this December 2018 bumper issue of African Health Sciences are on some aspects of diabetes mellitus.

Hence Cheserek and colleagues ${ }^{1}$ report on hyperuricemia and metabolic syndrome among university staff. They found that males were 3 times more likely to have hyperuricemia, and individuals with hyperuricemia were more likely to have metabolic syndrome and dyslipidemia. They call for programs for screening, preventing, and treating metabolic syndrome in people with hyperuricemia.

Nigerian workers, on the other hand, report on an audit of prescription patterns among diabetes mellitus patients in a tertiary institution. ${ }^{2}$ Liu and colleagues report on insulin resistance and diabetes mellitus ${ }^{3}$, while Ab El-Kader and others have a treatise on weight reduction on insulin resistance and adipokines regulation among obese diabetes mellitus patients. ${ }^{4}$

From Egypt, we have results of widespread screening of TB patients for diabetes mellitus. ${ }^{5}$ Chinese authors ${ }^{6}$ on the other hand have written for us the lack of association between the vitamin $\mathrm{D}$ gene and diabetic retinopathy, while Nigerian authors report on renal and lipid profile among diabetes mellitus patients. ${ }^{7}$

What about other non-communicable diseases? Work from South Africa reports on diagnostic performance of biomarkers for the identification of non-communicable diseases. ${ }^{8}$ Other authors from South Africa highlight walking as a feasible means of bringing about changes in blood pressure and anthropometric measurements. ${ }^{9}$ From Morocco, we have a study on risk factors for tetralogy of Fallot ${ }^{10}$, while Ghanaian workers report on hypertension ${ }^{11}$ and those from Nigeria highlight cardiovascular diseases as important causes of out of hospital deaths. ${ }^{12}$
Also from Nigeria, we have an interesting report on autonomic dysfunction among pre-dialysis chronic kidney disease patients. ${ }^{13}$ El-masry and colleagues from Egypt report breast cancer resistant protein in women with acute myeloid leukemia. ${ }^{14}$ The next four papers are on asthma, ${ }^{15}$ endometrial cancer ${ }^{16}$, red cell allo-immnization $^{17}$ and predictive value of hematological parameters in the diagnosis of brucellosis. ${ }^{18}$

There are other hematology papers such as Toye's work on PCR for the diagnosis of sickle cell anemia ${ }^{19}$, carbohydrate antigen $\mathrm{B} 19$ in sickle cell disease, ${ }^{20}$ and the effect of pan-retinal photo-coagulation ${ }^{21}$. Then comes mental health in practice ${ }^{22,23,24}$ followed by dental challenges. ${ }^{24,25}$ Now to infectious diseases: cytomegalovirus and HIV; ${ }^{26}$, markers of severity of HIV inflammation and coagulation $^{27}$; curative plants used by traditional healers to treat rhinitis ${ }^{28}$, as well as counselling long distance drivers for HIV $^{29}$ feeding challenges of HIV exposure to infants with unrepaired cleft lip. ${ }^{30}$

Keeping with the infectious disease theme: Chinese authors report on TB in University freshmen ${ }^{31}$; while Malaysian scientists report genetic diversity of hepatitis BCDE co-ineftion. ${ }^{32}$, and Nigerians report on influenza respiratory tract infection. ${ }^{33}$

A treatise on infectious diseases would be incomplete without malaria ${ }^{34}$; brucellosis ${ }^{35}$; Candida albicans ${ }^{36}$; Culex pipiens; ${ }^{37,38}$; antibiotic prescriptions ${ }^{39}$; and antibiotic resistance with the so called super bugs! $!^{40}$

\section{Now to mother newborn and child health issues.}

From Ethiopia, we have an interesting paper on low birthwieght ${ }^{41}$; while Ugandan authors report on post discharge mortality. ${ }^{42}$

Tanzania researchers report on heavy metals in urine of

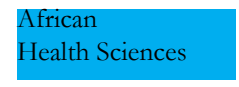

(C) 2018 Tumwine JK. Licensee African Health Sciences. This is an Open Access article distributed under the terms of the Creative commons Attribution License (https://creativecommons.org/licenses/BY/4.0), which permits unrestricted use, distribution, and reproduction in any medium, provided the original work is properly cited. 
children living near industries ${ }^{43}$, while Tunisian authors report on exercise among cystic fibrosis children. ${ }^{44}$

Ghanaian authors on the other hand write about geophagia in pregnancy. ${ }^{45}$ Is domestic violence ever justifiable? See what Ethiopian researchers are saying. ${ }^{46}$

Anaestesiologists: you have some articles to ponder: effect of remifentanil versus dexmedetomidine during surgery ${ }^{47}$, and clonidine pre-medication and bupivacaine spinal anaesthesia. ${ }^{48}$

The treatise ends with two disparate but interesting immunology papers ${ }^{49,50}$. As we go to press, East Africa is facing a number of unexpected challenges: a very serious boat accident on Lake Victoria that claimed innocent lives plus the danger posed by the war and Ebola epidemic in Eastern DRC. Watch the space!

\section{References}

1. Cheserek MJ, Shi Y, Le G. Association of hyperuricemia with metabolic syndrome among university workers: sex and occupational differences. Afri Health Sci. 2018;18(4): 842-851. https://dx.doi.org/10.4314/ahs.v18i4.2

2. Olamoyegun MA, Akinlade AT, Ala OA. Audit of insulin prescription patterns and associated burden among diabetics in a tertiary health institution in Nigeria. Afri Health Sci. 2018;18(4): 852-864. https://dx.doi. org/10.4314/ahs.v18i4.3

3. Liu Y, Zheng L, Kong H, Wang Q, Tian X. HMGA1 variant IVS5-13insC is associated with insulin resistance and type 2 diabetes: an updated meta-analysis. Afri Health Sci. 2018;18(4): 865-872. https://dx.doi.org/10.4314/ ahs.v18i4.4

4. Abd El-Kader SM, Al-Jiffri OH. Impact of weight reduction on insulin resistance, adhesive molecules and adipokines dysregulation among obese type 2 diabetic patients. Afri Health Sci. 2018;18(4): 873-883. https://dx. doi.org/10.4314/ahs.v18i4.5

5. Gadallah M, Amin W, Fawzy M, Mokhtar A, Mohsen A. Screening for diabetes among tuberculosis patients: a nationwide population-based study in Egypt. Afri Health Sci. 2018;18(4): 884-890. https://dx.doi.org/10.4314/ ahs.v18i4.6

6. Jiao J-H, Li Y, Xu S, Wu J, Yue S, Liu L. Association of FokI, TaqI, BsmI and ApaI polymorphisms with diabetic retinopathy: a pooled analysis of case-control studies. Afri Health Sci. 2018;18(4): 891-899. https://dx.doi. org/10.4314/ahs.v18i4.7
7. Aderibigbe MA, Obafemi TO, Olaleye MT, Akinmoladun AC. Effects of gender, age and treatment duration on lipid profile and renal function indices in diabetic patients attending a teaching hospital in South-Western Nigeria. Afri Health Sci. 2018;18(4): 900-908. https://dx.doi. org/10.4314/ahs.v18i4.8

8. Businge CB, Longo-Mbenza B, Adeniyi OV, Muaka MM, Lelo GM, Nkanga MSN, Kavembe J-M, Buassa-bu-Tsumbu B, Kabangu J-R M, Ter Goon D. Diagnostic performance of several biomarkers for identification of cases of non-communicable diseases among Central Africans. Afri Health Sci. 2018;18(4): 909-916. https://dx. doi.org/10.4314/ahs.v18i4.9

9. Gradidge P J-L, Golele PN. Walking as a feasible means of effecting positive changes in BMI, waist, and blood pressure in black South African women. Afri Health Sci. 2018;18(4): 917-921. https://dx.doi.org/10.4314/ahs. v18i4.10

10. EL Bouchikhi I, Belhassan K, Moufid FZ, Houssaini MI, Bouguenouch L, Samri I, Bouhrim M, Ouldim K, Atmani S. GATA4 molecular screening and assessment of environmental risk factors in a Moroccan cohort with tetralogy of Fallot. Afri Health Sci. 2018;18(4): 922- 930. https://dx.doi.org/10.4314/ahs.v18i4.11

11. Agyei-Baffour P, Tetteh G, Quansah DY, Boateng D. Prevalence and knowledge of hypertension among people living in rural communities in Ghana: a mixed method study. Afri Health Sci. 2018;18(4): 931-941. https:/ /dx.doi. org/10.4314/ahs.v18i4.12

12. Adegoke O, Awolola NA, Ajuluchukwu JN. Prevalence and pattern of cardiovascular-related causes of out-of- hospital deaths in Lagos, Nigeria. Afri Health Sci. 2018;18(4): 942-949. https://dx.doi.org/10.4314/ahs. v18i4.13

13. Onodugo O, Arodiwe E, Okoye J, Ezeala B, Onodugo N, Ulasi I, Ijoma C. Prevalence of autonomic dysfunction among pre-dialysis chronic kidney disease patients in a tertiary hospital, South East Nigeria. Afri Health Sci. 2018;18(4): 950-957. https://dx.doi.org/10.4314/

ahs.v18i4.14

14. El-Masry MW, Gouda HM, Shaheen IA, Edesa W, Hassan NM, Ramzy R. Breast cancer resistance protein (BCRP) gene expression in a cohort of adult Egyptian patients with acute myeloid leukemia. Afri Health Sci. 2018;18(4): 958-964. https://dx.doi.org/10.4314/ahs. v18i4.15

15. Simba J, Marete I, Waihenya R, Kombe Y, Mwangi A, Mburugu P, Ogaro F. Knowledge and perceptions on

African Health Sciences Vol 18 Issue 4, December, 2018 
childhood asthma among care-takers of children with asthma at a National Referral Hospital in Western Kenya: a descriptive study. Afri Health Sci. 2018;18(4): 965-971. https://dx.doi.org/10.4314/ahs.v18i4.16

16. Nithin KU, Sridhar MG, Srilatha K, Habebullah S. CA 125 is a better marker to differentiate endometrial cancer and abnormal uterine bleeding. Afri Health Sci. 2018;18(4): 972-978. https://dx.doi.org/10.4314/ahs.v18i4.17

17. Obi EI, Pughikumo CO, Oko-jaja RI. Red blood cell alloimmunization in multi-transfused patients with chronic kidney disease in Port Harcourt, South-South Nigeria. Afri Health Sci. 2018;18(4): 979-987. https://dx. doi.org/10.4314/ahs.v18i4.18

18. Balın ŞÖ, Tartar AS, Akbulut A. The predictive role of haematological parameters in the diagnosis of osteoarticular brucellosis. Afri Health Sci. 2018;18(4): 988-994. https://dx.doi.org/10.4314/ahs.v18i4.19

19. Toye ET, Marle GV, Hutchins W, Abgabiaje O, Okpuzor J. Single tube allele specific PCR: a low cost technique for molecular screening of sickle cell anaemia in Nigeria. Afri Health Sci. 2018;18(4): 995-1002. https://dx.doi. org/10.4314/ahs.v18i4.20

20. Manafa P, Okocha C, Nwogho B, Aneke J, Okpara PSD, lbeh N, Chukwuma G, Manafa V, Nwane E. A comparative study of carbohydrate antigen 19-9 in sickle cell disease subjects and controls in Nnamdi Azikiwe University Teaching Hospital, Nnewi, Nigeria. Afri Health Sci. 2018;18(4): 1003-1009. https://dx.doi.org/10.4314/ahs. v18i4.21

21. Inan S, Polat O, Yigit S, Inan UU. PASCAL laser platform produces less pain responses compared to conventional laser system during the panretinal photocoagulation: a randomized clinical trial. Afri Health Sci. 2018;18(4): 1010-1017. https://dx.doi.org/10.4314/ahs. v18i4.22

22. Harouni GG, Mahdavi MRV, Naghdi S, Armoon B, Fazaeli AA, Ghiasvand H, Noroozi M, Ahounbar E. Decomposing disparity in adult individual's mental health in Tehran among lower and higher economic groups; an Oaxaca- Blinder analysis on urban HEART Surveyround 2. Afri Health Sci. 2018;18(4): 1018-1026. https:// dx.doi.org/10.4314/ahs.v18i4.23

23. Phehlukwayo SM, Tsoka-Gwegweni JM. Investigating the influence of contextual factors in the coordination of chronic mental illness care in a district health system. Afri Health Sci. 2018;18(4): 1027-1035. https://dx.doi. org/10.4314/ahs.v18i4.24
24. Al-Alimi KR, Razak AAA, Saub R. Is Khat chewing habit a risk factor for occlusal caries progression? Afri Health Sci. 2018;18(4): 1036-1045. https://dx.doi. org/10.4314/ahs.v18i4.25

25. Sen N, Asawa K, Bhat N, Tak M, Sultane P, Chakravarty $\mathrm{T}$. A comparative assessment of caries risk using cariogram among smokers and smokeless tobacco users in india - a cross-sectional study. Afri Health Sci. 2018;18(4): 1046-1056. https://dx.doi.org/10.4314/ahs.v18i4.26 26. Udeze A, Odebisi-Omokanye M, Ajileye T. Cytomegalovirus infection among Human Immunodeficiency Virus (HIV) infected individuals on highly active anti-retroviral therapy in North-Central Nigeria. Afri Health Sci. 2018;18(4): 1057-1065. https://dx.doi.org/10.4314/ahs. v18i4.27

27. Hoffman M, Ipp H, Phatlhane DV, Erasmus RT, Zemlin AE. E-Selectin and markers of HIV disease severity, inflammation and coagulation in HIV-infected treatment-naïve individuals. Afri Health Sci. 2018;18(4): 1066-1075. https://dx.doi.org/10.4314/ahs.v18i4.28

28. Semenya SS, Maroyi A. Ethnobotanical study of curative plants used by traditional healers to treat rhinitis in the Limpopo Province, South Africa. Afri Health Sci. 2018;18(4): 1076-1087. https://dx.doi.org/10.4314/ahs. v18i4.29

29. Ijeoma A, Ejikeme A, Theodora O, Chika O. Knowledge, attitude, willingness of HIV counseling and testing and factors associated with it, among long distant drivers in Enugu, Nigeria: an opportunity in reduction of HIV prevalence. Afri Health Sci. 2018;18(4): 1088-1097. https://dx.doi.org/10.4314/ahs.v18i4.30

30. Visser EE, Krüger EE, Kritzinger AMAM. Feeding difficulties in infants with unrepaired cleft lip and palate and HIV-exposure. Afri Health Sci. 2018;18(4): 1098-1108. https://dx.doi.org/10.4314/ahs.v18i4.31

31. Wang Y-H, Tian Y, Gao J-X, Lei C-K, Liu Y-W, Han Z-M, Xing H, Yan C, Zhou L. Tuberculosis prevalence among university freshmen in Zhengzhou, China, during 2004-2013. Afri Health Sci. 2018;18(4): 1109-1116. https://dx.doi.org/10.4314/ahs.v18i4.32

32. Hudu SA, Niazlin MT, Nordin SA, Tan SS, Omar H, Shahar H, Mutalib NA, Sekawi Z. Genetic diversity of hepatitis B co-infection with hepatitis C, D and E viruses among Malaysian chronic hepatitis B patients. Afri Health Sci. 2018;18(4): 1117-1133. https://dx.doi.org/10.4314/ ahs.v18i4.33

33. Odun-Ayo F, Odaibo G, Olaleye D. Influenza virus 
A (H1 and H3) and B co-circulation among patient presenting with acute respiratory tract infection in Ibadan, Nigeria. Afri Health Sci. 2018;18(4): 1134-1143. https:// dx.doi.org/10.4314/ahs.v18i4.34

34. Musoke D, Karani G, Morris K, Ndejjo R, Atusingwize E, Guwatudde D, Musoke MB. Integrated approach to malaria prevention at household level in rural communities in Wakiso district, Uganda: impact evaluation of a pilot project. Afri Health Sci. 2018;18(4): 1144-1156. https://dx.doi.org/10.4314/ahs.v18i4.35

35. Ismael AB, Mergani A, Salim A, Mostafa S, Alkafaween I. Interferon- $\gamma$ receptor- 1 gene promoter polymorphisms and susceptibility for brucellosis in Makkah region. Afri Health Sci. 2018;18(4): 1157-1165. https:// dx.doi.org/10.4314/ahs.v18i4.36

36. Kadry AA, El-Ganiny AM, El-Baz AM. Relationship between Sap prevalence and biofilm formation among resistant clinical isolates of Candida albicans. Afri Health Sci. 2018;18(4): 1166-1174. https://dx.doi.org/10.4314/ ahs.v18i4.37

37. Tabbabi A, Laamari A, Cheikh RB, Jha IB, Daaboub J, Cheikh HB. Resistance development and insecticide susceptibility in Culex pipiens pipiens, an important vector of human diseases, against selection pressure of temephos and its relationship to cross-resistance towards organophosphates and pyrethroids insecticides. Afri Health Sci. 2018;18(4): 1175-1181. https://dx.doi.org/10.4314/ahs. v18i4.38

38. Tabbabi A, Daaboub J, Cheikh RB, Laamari A, Feriani M, Boubaker C, Jha IB, Cheikh HB. Resistance status to deltamethrin pyrethroid of Culex pipiens pipiens (Diptera: Culicidae) collected from three districts of Tunisia. Afri Health Sci. 2018;18(4): 1182-1188. https://dx.doi. org/10.4314/ahs.v18i4.39

39. Adisa R, Orherhe OM, Fakeye TO. Evaluation of antibiotic prescriptions and use in under-five children in Ibadan, SouthWestern Nigeria. Afri Health Sci. 2018;18(4): 1189-1201. https://dx.doi.org/10.4314/ahs.v18i4.40

40. Mansour W. Tunisian antibiotic resistance problems: three contexts but one health. Afri Health Sci. 2018;18(4): 1202-1203. https://dx.doi.org/10.4314/ahs.v18i4.41

41. Adane T, Dachew BA. Low birth weight and associated factors among singleton neonates born at Felege Hiwot referral hospital, North West Ethiopia. Afri Health Sci. 2018;18(4): 1204-1213. https://dx.doi.org/10.4314/ ahs.v18i4.42
42. Nemetchek BR, Liang L(D), Kissoon N, Ansermino JM, Kabakyenga J, Lavoie PM, Fowler-Kerry S, Wiens MO. Predictor variables for post-discharge mortality modelling in infants: a protocol development project. Afri Health Sci. 2018;18(4): 1214-1225. https://dx.doi. org/10.4314/ahs.v18i4.43

43. Mahugija JAM, Kasenya ZS, Kilulya KF. Levels of heavy metals in urine samples of school children from selected industrial and non-industrial areas in Dar es Salaam, Tanzania. Afri Health Sci. 2018;18(4): 1226-1235. https://dx.doi.org/10.4314/ahs.v18i4.44

44. Abdelbasset WK, Soliman GS, Elshehawy AA, Alrawaili SM. Exercise capacity and muscle fatiguability alterations following a progressive maximal exercise of lower extremities in children with cystic fibrosis. Afri Health Sci. 2018;18(4): 1236-1242. https://dx.doi.org/10.4314/ ahs.v18i4.45

45. Sackey DS, Larbie C, Mensah FO. Geophagia, nutrition and health of women with pregnancy-induced hypertension. Afri Health Sci. 2018;18(4): 1243-1254. https:// dx.doi.org/10.4314/ahs.v18i4.46

46. Guracho YD, Bifftu BB. Women's attitude and reasons toward justifying domestic violence in Ethiopia: a systematic review and meta-analysis. Afri Health Sci. 2018;18(4): 1255-1266. https://dx.doi.org/10.4314/ahs.v18i4.47

47. Okello MO, Mung'ayi V, Adam R, Kabugi J. A comparison of risk of hypotension using standard doses of remifentanil versus dexmedetomidine infusions in adult patients undergoing surgery under general anaesthesia at the Aga Khan University Hospital, Nairobi. Afri Health Sci. 2018;18(4): 1267-1282. https://dx.doi.org/10.4314/ ahs.v18i4.48

48. Adegboye MB, Kolawole IK, Bolaji BO. Dose related effects of oral clonidine pre-medication on bupivacaine spinal anaesthesia. Afri Health Sci. 2018;18(4): 1283-1291. https://dx.doi.org/10.4314/ahs.v18i4.49

49. Ji X-B, Luo J, Feng X-L, Xu Q-L, Man T, Zhao D, Li X-F, Zhang G-P, Chen P-Y. The immunomodulatory peptide bursopentin (BP5) enhances proliferation and induces sIgM expression in DT40 cells. Afri Health Sci. 2018;18(4): 1292-1302. https://dx.doi.org/10.4314/ahs. v18i4.50

50. Karakuş F, Eyol E, Yılmaz K, Ünüvar S. Inhibition of cell proliferation, migration and colony formation of LS174T Cells by carbonic anhydrase inhibitor. Afri Health Sci. 2018;18(4): 1303-1310. https://dx.doi.org/10.4314/ ahs.v18i4.51

African Health Sciences Vol 18 Issue 4, December, 2018 